\title{
Lodewijk de Bils' and Tobias Andreae's Cartesian Bodies: Embalmment Experiments, Medical Controversies and Mechanical Philosophy
}

\author{
Pietro Daniel Omodeo \\ Ca' Foscari University of Venice \\ pietrodaniel.omodeo@unive.it
}

\begin{abstract}
This essay concerns the penetration of Cartesian ideas into medical practices and theories related to new anatomical techniques in the mid seventeenth century, and with their transfer from the Netherlands to Flanders and Germany. It begins with an overview of debates on embalmment and dissection, which were provoked by the work of the Flemish anatomical practitioner Lodewijk de Bils (1624-1671). The presence of Cartesian themes in these debates is here considered, followed by an examination of the reception and implementation of De Bils' techniques by medical Cartesians in Germany, with a focus on the embalmment experiments conducted in Frankfurt (Oder) by De Bils' former assistant, professor Tobias Andreae (1633-1685), and finally, an assessment of the Cartesian framework underlying these medical experimentation and debates.
\end{abstract}

\section{Keywords}

Lodewijk de Bils - Tobias Andreae - medical Cartesianism - embalmment experiments - Descartes' reception

* Department of Philosophy and Cultural Heritage, Università Ca' Foscari, Venezia, Italia. I would like to thank Christoph Lüthy, Rodolfo Garau, Andrea Strazzoni and the journal's anonymous referees for their comments and suggestions; the librarians of the Max Planck Institute for the History of Science, Berlin, for their valuable support with bibliographical research and the digitization of sources; and Hester van den Elzen for her help with a Dutch text. 
In 1679 the Cartesian professor of medicine at Frankfurt on Oder, Tobias Andreae, presided over a disputation On the Conjunction of Mind and Body, in which his pupil Clemens Joseph Brecht defended the thesis that "it is a gross prejudice [...] to believe that there is a real distinction between medicine and philosophy." Andreae and Brecht regarded Descartes' philosophy, as presented in the Principia philosophiae, Les passions de l'âme and Traité de l'homme, as a viable mechanistic framework for anatomy and physiology at a time when mechanism triumphed as an explanatory means in various scientific fields, including medicine. ${ }^{2}$

The central role played by medicine in Descartes' intellectual endeavor has increasingly attracted scholarly attention in recent years. Most significantly, Vincent Aucante has provided historians of philosophy, science and medicine with an accurate reconstruction of Descartes' 'philosophie médicale,' while several studies have deepened our understanding of particular aspects of his medical conceptions. Justin Smith has gone so far as to affirm that 'Descartes' was a medical philosophy to the extent that he saw medicine as integral to the project of philosophy."3 But the inverse influence of Cartesian philosophy on medical conceptions and debates ought to be stressed as well. There were many physicians among Descartes' correspondents and early supporters, among them Cornelis van Hoghelande and Henricus Regius. ${ }^{4}$ In the context of the receptio Cartesiana the boundaries between natural philosophy and medicine were often blurred.

In this essay I will assess the infiltration of medical practices with Cartesian ideas, as well as the question of how contemporary debates hinged upon new anatomical techniques. First I will deal with debates on embalmment and dissection in the Netherlands and Flanders in the 1650 s and 166os, notably in relation to the work of the Flemish practitioner Lodewijk de Bils, and highlight the Cartesian themes we encounter in these debates. I will then examine the reception and implementation of De Bils' techniques by medical Cartesians,

1 Tobias Andreae (praeses) and Clemens Joseph Brecht (respondens), De conjugio mentis et corporis ad Hipp. aphor. VI. sect. II. "Quicunque aliqua corporis parte dolentes, plerumque dolores non sentiunt his mens agrotat" ([Frankfurt (Oder)], 1679), f. Aur: "praejudicio hoc crasso, et ipsis indecenti se decipientes, quod putent inter Medicinam et Philosophiam realem distinctionem dari."

2 Cf. Domenico Bertoloni Meli, Mechanism, Experiment, Disease: Marcello Malpighi and Seventeenth-Century Anatomy (Baltimore, MD, 2011).

3 Vincent Aucante, La philosophie médicale de Descartes (Paris, 2006); and Justin E.H. Smith, "Heat, Action, Perception: Models of Living Beings in German Medical Cartesianism," in Mihnea Dobre and Tammy Nyden, eds., Cartesian Empiricism (Dordrecht, 2013), 105-123, at 106.

4 Cf. Gerrit Arie Lindeboom, Descartes and Medicine (Amsterdam, 1979), ch. 2. 
focusing on the embalmment experiments conducted in Frankfurt (Oder) by his former assistant, professor Tobias Andreae, together with Andreae's entourage.

My reconstruction is based on several interrelated publications: Ludovici de Bils responsio ad epistolam Tobiae Andreae [De Bils' Response to Tobias Andreae's Letter] (Marburg, 1678) and Andreae's Bilanx exacta Bilsianae et Caluderianae balsamationis [Accurate Assessment of De Bils' and Clauder's Embalmment Techniques] (Amsterdam, 1682), which was written in reaction to the ducal physician of Saxony, Gabriel Clauder's work Methodus balsamandi corpora humana, aliaque majora sine evisceratione et sectione hucusque solita [Method for the Embalmment of Human Bodies and Other Major (Bodies) Accomplished without Evisceration and Dissection] (Altenburg, 1679). I will also take into account a series of other related primary sources, not least the writings by De Bils and his opponents. Finally, I will assess the Cartesian elements in such medical experiments and debates.

\section{The Rise of a Medical Practitioner}

In early-capitalist northern Europe, a flourishing market of medical instruments and scientific curiosities, together with the rise of new academic centers, allowed 'illiterate' practitioners to work in close connection with reputable professors and accomplish unprecedented careers. ${ }^{5}$ The scientific ascent of Lodewijk de Bils, inventor of embalmment techniques, is a case in point. His realization of spectacular specimina for both the anatomical theatre of Leiden and the University of Louvain, his preparation of stained cadavers displaying uncorrupted organs, and his museum project in Rotterdam ensured his reputation among the learned elite internationally. Scholars linked to the Royal Soci-

5 Dániel Margócsy, Commercial Visions: Science, Trade, and Visual Culture in the Dutch Golden Age (Chicago, IL and London, 2014), especially chap. IV, "Anatomical Specimens in the Republic of Letters," 108ff. Also see Harold J. Cook, "Time's Bodies: Crafting the Preparation and Preservation of Naturalia," in Pamela H. Smith and Paula Findlen, eds., Merchants and Marvels: Commerce, Science, and Art in Early Modern Europe (New York, NY and London, 2002), 223-247. The seminal work on De Bils' life and work is Jan Reinier Jansma, Louis de Bils en de anatomie van zijn tijd (Hoogeveen, 1919), which offers a brief and useful overview of his achievements and contacts, but does not expand on the philosophical context of the anatomical debates of his time, in particular Cartesianism, nor does it investigate the connection with his pupil Andreae in any detail. 
ety knew and respected him, in particular Robert Boyle and Samuel Hartlib. ${ }^{6}$ An unknown French gentleman and pupil of Pierre Gassendi's reported on him in a letter translated by the mathematician John Pell and printed by Boyle: "his two secrets are that of embalming, and the opening of dead body's without the spilling of Blood."7 De Bils established himself as an anatomical entrepreneur building close but unsteady relations with cultivated elites and patrons. It is not clear how he began his activities, but he apparently started them at the young age of thirteen, when he lived in Rouen. ${ }^{8}$ He continued his experiments in Flanders and the Netherlands, and his preparation of embalmed bodies and specimens became widely known and discussed. Henry Oldenburg, for one, visited him in Rotterdam and relayed his views to Christian Huygens. ${ }^{9}$

The usefulness of De Bils' method of preservation for medical research was unquestioned. It permitted one to examine and display the inner parts of an organism without looking for 'fresh' cadavers, and without loss of blood. In 1662, the Louvain professor of mathematics and anatomy Gerard van Gutschoven wrote a very positive report on five embalmed bodies that De Bils exhibited in Brussels. The cadavers of four men and a woman had been embalmed and dissected in such a way that one could inspect their inner parts, muscles, veins, arteries and lymphatic vessels, as well as their organs, and even their brains. Van Gutschoven did not fail to emphasize the pedagogical advantages of such specimens:

This invention is very useful and even necessary for the anatomical schools. In fact, one can easily explain the parts [of the body] in any

6 The English mathematician John Pell translated a text by De Bils, The Coppy of a Certain Large Act... Touching the Skill of a Better Way of Anatomy of Mans Body (London, 1659), which was printed under Boyle's auspices and dedicated to Hartlib. Cf. Dániel Margócsy, "Advertising Cadavers in the Republic of Letters: Anatomical Publications in the Early Modern Netherlands," British Journal for the History of Science, 42 (2009), 187-210, at 189.

7 De Bils, Coppy, 14. The name of the French gentleman is not revealed in the source.

8 This information is repeated by most secondary sources touching upon De Bils, e.g. Cook, "Time's Bodies," 229.

9 Henry Oldenburg to Christian Huygens (Rotterdam, 3 August 1661), in Alfred Rupert Hall and Marie Boas Hall, eds., The Correspondence of Henry Oldenburg, 13 vols. (Madison, wi and Milwaukee, WI, 1965-1986), 1:411: "Mr de Bils me traite icy avec grande humanité, et semble d'entendre tres-bien l'Anatomie, et este resolu de maintenir et de faire bon son party. Il pretend de scavoir exactement le secret de la nutrition, comme aussi dela generation dela semence, et de la separation de l'urine, et de son passage du foye dans les reins. Le temps enseignera tout." 
season. Moreover, one can show students an autopsy in such a manner that the function [ratio] of all parts alongside their connection, figure, quantity and insertion will be firmly impressed in the memory. This will fully prepare them for the occasion of practicing anatomy on a fresh corpse [in recente subjecto]. They will recognize at first glance [primo intuitu percipiendo] what would otherwise take many years [to apprehend], since fresh corpses are not always at disposal. ${ }^{10}$

Around 1651 De Bils became associated with the Leiden professor of anatomy, Joannes van Horne, who received his donation of several specimens for the university's anatomical theater." De Bils' preparations quickly became famous. For instance, the German physician Anton Deusing extolled his admirable technique, although he had never seen De Bils' specimens or met him in person. In some "physico-anatomical exercises" on the lymphatic system, discussed at Groningen in 166o, Deusing even dealt with the question of whether De Bils should be considered an "anatomicus taumaturgus" [miraculous anatomist] according to rumors and fame (ex rumore saltem ac fama): "He really is a miracle maker, and so far an inimitable one, if that which is reported about him is true, as I do not dare to doubt."12

Deusing's statement was based on some of De Bils' publications as well as several individuals' positive opinions: he hinted at the fact that a nobleman was ready to pay for De Bils' specimens. Moreover, Deusing referred to the positive opinion of the Groningen rector and theology professor, Samuel Desmarets, a defender of the legitimacy of the new philosophy in the context of early Dutch Cartesian polemics. ${ }^{13}$

Gerard van Gutschoven, Repertum (Brussels, 4 November 1662), in Luis de Bils, Responsio ad epistolam Tobiae Andreae... qua ostenditur verus usus vasorum hactenus pro lymphaticis habitorum (Marburg, 1678), 26-29, at 29: "Inventio est Scholis Anatomicis utilissima ac necessaria; ea quippe ratione cunctis anni tempestatibus commode fieri potest explicatio

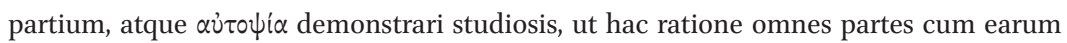
connexione, figura, quantitate atque insertione memoriae imprimantur, uti data occasione in recente subjecto Anatomiam exerceant, promptiores sint ad cuncta, primo intuitu percipiendum, quod alias fieri nequit, nisi longaevo annorum spatio, quia subjecta recentia non semper sunt ad manum."

On the relation between De Bils and Van Horne, cf. Tim Huisman, The Finger of God: Anatomical Practice in 17th-Century Leiden (Leiden, 2009), especially 84-87.

12 Anton Deusing, Erercitationes [sic] physico-anatomicae, de nutrimenti in corpore elaboratione (Groningen, 1660), 277: "Vere Taumaturgus est, vere inimitabilis hactenus, si vera sunt, ut dubitare hactenus non ausim, quae de ipso referuntur." Ibid., 278. 
In 1659 De Bils produced an advertising pamphlet in three languages: Dutch, Latin and English. ${ }^{14}$ The advertisement was aimed to raise the considerable sum of 20,00o pounds, which were needed to set up an anatomical museum in Rotterdam. De Bils claimed that the museum would enhance the understanding of human physiology to the advantage of experts and laymen alike. In fact, the museum would exhibit inner organs to a wide public of scholars and curious people; it would also showcase veins and arteries, muscles, nerves and other admirabilia. De Bils claimed that his anatomical preparations could be shown to students in any season, as they were not subject to rotting and could resist the summer heat. He also intended to make the circulation of blood visible, and thereby render William Harvey's discovery perceptible to the naked eye. Most importantly, he stated that his preparations would further the advance of science. In this respect he boasted about his own discoveries concerning the lymphatic system, in particular the determination of the 'true' function of the thoracic duct (verus usus ductus chyliferi).${ }^{15} \mathrm{He}$ also declared himself proud of the specimens that he had donated to the "very famous University of Leiden." An attestatio (certificate) by Professor Joann van Horne dated 1 May 1651 was attached to the publication. It described the specimens in the Leiden anatomical theatre (anatomical parts of human and animal bodies, organs and skeletons) and testified to their high quality. ${ }^{16}$

Soon, however, De Bils' relations with the university elites became strained. In his writings, he bragged that anybody could learn from his preparations more rapidly than by reading existing medical literature or by listening to bookish professors. Additionally, he claimed that he could contribute to the advance of anatomy in a more secure manner than many an illustrious scholar. The tenor of his claims can be drawn from his pamphlet-like Omnibus verae anatomes studiosis [To All Scholars in True Anatomy] (1660):

I will show more clearly than the midday sun (unless somebody is blind like a mole) that everything that has been so far communicated to us by ancient and recent scholars, or that has been written down relative to our

De Bils, Kopye van zekere ampele acte van Jr. Louijs de Bils (Rotterdam, 1659); idem, Exemplar fusioris codicilli... In quo agitur de vera humani corporis anatomia (Rotterdam, 1659); idem, Coppy. The last edition (London, 1659) was made possible thanks to the intervention of Boyle. See Andrew Cunningham, The Anatomist Anatomis'd: An Experimental Discipline in Enlightenment Europe (Farnham, 2010), 233-234.

15 De Bils, Exemplar fusioris codicilli, 4 . The year 1659 also saw the publication in Latin of his Epistolica dissertatio, qua verus hepatis circa chylum, et pariter ductus chiliferi hactenus ducti usus, docetur (Rotterdam, 1659). The Dutch publication dates back to 1658. Ibid., 7-8. 
natural functions [...] is clearly false and a mere passing comment from Masters who can barely discern anything through the fence through which they inspect nature. With the same ease I will demonstrate that today's medical praxis is entirely deprived of reasons and full of dangerous uncertainties. ${ }^{17}$

One of the controversial issues was De Bils' description and explanation of the lymphatic system. According to him, it was a circulatory system akin, and complementary, to the blood system. Among other things, he deemed that the lymph transported material necessary to produce blood 'fermentation' in the heart for the production of cardiac pulsation. As far as this aspect is concerned, De Bils' perspective looks similar but not identical to Descartes' in the Traité de l'homme. Both authors supported a chemical-mechanical theory of the heartbeat, according to which it was produced by an expansion of the blood, as opposed to Harvey's reliance on an Aristotelian vis pulsiva. ${ }^{18}$

Although Descartes' physiological work had not yet been published, he had already presented the explanation of the heartbeat as an important test case of his method in the famous Discours of $1637 .{ }^{19}$ Moreover, the possibility of developing a Cartesian medicine had been widely and controversially discussed in the Netherlands. In a series of disputations that sparked off the so-called 'Utrecht crisis,' Henricus Regius presented a medical application of Cartesian physics as early as in $1641 .{ }^{20}$ In the collection of disputations, Physiologia sive

Idem, Omnibus verae anatomes studiosis (Rotterdam, 166o), f. 2r-v: “Ostendam sole meridiano clarius (nisi quis instar talpae caecutiat) quidquid hactenus ab antiquis vel recentioribus traditum est, scriptove consignatum quoad functiones nostras naturales, nullo nisi fundamento aut judicio, sed palam esse falsum, merumque commentum Magistrorum, qui vix per transennam intelligunt aut vident, unde naturam auspicentur [...]. Pari facilitate faciam ut intelligant, hodiernae medicinae praxin plane rationis expertem esse, periculosae aleae plenam [...]."

Francesco Trevisani, Descartes in Germania: La ricezione del cartesianesimo nella facoltà filosofica e medica di Duisburg (1652-1703) (Milan, 1992), 137-145. On the Cartesian and postCartesian debates on the heartbeat, see Marjorie Grene, "Descartes and the Heart Beat: A Conservative Innovation," in Jed Z. Buchwald and Allan Franklin, eds., Wrong for the Right Reason (Dordrecht, 2005), 91-97; Lucian Petrescu, "Descartes on the Heartbeat: The Leuven Affair," Perspectives on Science, 21 (2013), 397-428; Rodolfo Garau, "Springs, Nitre, and Conatus: The Role of the Heart in Hobbes's Physiology and Animal Locomotion," British Journal for the History of Philosophy, 24 (2016), 1-26.

19 René Descartes, CEuvres, eds. Charles Adam and Paul Tannery, 12 vols. (Paris, ([1897-1913], 1982), 6:46-55.

20 See Theo Verbeek, Descartes and the Dutch: Early Reactions to Cartesian Philosophy 1637$165^{\circ}$ (Carbondale, IL and Edwardsville, IL, 1992), 13-33. 
cognitio sanitatis [Physiology or Knowledge of Health] (1641), he proposed the theory of a "lightless fire" (ignis non lucidus) produced in the heart by blood fermentation, which was supposed to trigger the circulation of blood. ${ }^{21}$ Unlike Descartes, he regarded the heartbeat not only as the effect of fermentation, but also of the circulation of spirits, which the veins bring forth and back from and to the heart. Hence, according to Regius the diastole is not only produced by the blood expansion, but also induced by the streaming of the spirits in the fibers of the heart. ${ }^{22}$

Moreover, Regius hinted at a possible functional interconnection between the lymphatic vessels and blood circulation. He surmised that the lymphatic vessels contribute to the transportation of the chyle to the liver, which converts it into another juice, the chymus. The latter is conveyed to the heart, where it mixes with the blood that comes back from the periphery and gets 'cooked,' or 'digested' (the Latin term is coctio). As a result of such "pulse boiling" (ebullitio pulsifica), perfect blood is restored. Regius saw the whole process as a sort of chemical fermentation in which no occult virtues (non aliqua vi attractrice) should be postulated. Rather, it rested on mechanical processes, in which only the fluidity of the juices and the pressure of the parts and the organs should be taken into account. ${ }^{23}$

In the course of the polemics, Descartes repudiated his follower's views for their materialistic bent, such as the potential reduction of the mind to a bodily mode, or the claim of the indemonstrability of the immortality of the soul and the existence of God, as discussed in Regius' Fundamenta physices [Foundations of Physics] of $1646 .{ }^{24}$ In spite of their eventual break-up, Regius' dissemination of notions concerning innate heat and blood circulation offered a

Cf. Henricus Regius, Physiologia sive cognitio sanitatis (Utrecht, 1641), in Erik-Jan Bos, The Correspondence between Descartes and Henricus Regius (Utrecht, 2002), "Appendix," 195248, 207-208 (De calido nativo), 214-215 (De pulsu) and 215-216 (De sanguinis circulatione). Thomas Fuchs, The Mechanization of the Heart: Harvey and Descartes (Rochester, NY, 2001), 147 .

23 Ibid., 212-214, "disputationes secunde, pars prior," especially theses 9 and 10. Annie BitbolHespéries pointed to the originality of Regius' treatment of the milky vessels in a useful essay on his reception and reworking of Descartes in his Physiologia: Annie Bitbol-Hespéries, "Descartes et Regius: Leur pensée médicale," in Theo Verbeek, ed., Descartes et Regius: Autour de l'Explication de l'esprit humain (Amsterdam and Atlanta, GA, 1993), 47-68, at 67-68.

24 For a summary of Regius' controversial views on Cartesian philosophy, see Roger Ariew et al., Historical Dictionary of Descartes and Cartesian Philosophy (Lanham, MD, Toronto and Oxford, 2003), s.v. "Regius," esp. 220. For a more detailed analysis see Theo Verbeek, “Regius' Fundamenta Physices," Journal of the History of Ideas, 55 (1994), 533-551. 
Cartesian 'research program' that might have underlined De Bils' investigation of the lymphatic system in its relation to blood fermentation. Tenets of the Cartesian program were the exclusion of forms, faculties and occult qualities from physiological explanations, and thus the identification of causal processes such as fermentation.

That De Bils was personally acquainted with Descartes' physiological manuscripts emerges from a passage in which he established an explicit connection between his own discoveries and Descartes' theses. Here, he claimed that his techniques would make Descartes' physiology intelligible. As he wrote to a patron, the unnamed dedicatee of a 1659 Epistolica dissertatio, qua verus hepatis circa chylum, et pariter ductus chiliferi... usus, docetur [Epistolary Dissertation Explaining the True Function of the Liver Concerning the Chyle as well as of the Chyle-Carrying Duct],

[y]ou will perhaps be astounded that I have so far published and dedicated so little to you. You should know that there are refined and erudite people who often and insistently requested the same from me, along with others who attempt in vain to extract something significant out of the Traité de l'homme left by the divine Descartes. For this reason it seems to me that I can satisfy their expectations and, at the same time, make their efforts useless, while I please you, with one and the same work. ${ }^{25}$

Actually, scholars trying to edit Descartes' Traité de l'homme faced the great difficulty that the manuscript lacked the images referred to in the text. Hence, much effort was made to produce apt illustrations. ${ }^{26}$ In the late 1650 s, Florentius Schuyl was preparing an illustrated edition of the work. Yet, this professorto-be of Leiden University, who was in 's-Hertogenbosch (or Den Bosch, Lat. Silva Ducalis) at the time, closely collaborated with the Leiden professors whose relations with De Bils rapidly became tainted. It is, therefore, likely that De Bils turned to the competing editorial project, the French edition with illustrations by his acquaintance, the Louvain professor Van Gutschoven. I will

25 De Bils, Epistolica dissertatio, 3: "Miraberis forsitan hasce tam paucula typis mandata tibique dedicata: ast scias, oro, esse (qui, idem, quod tu jam saepius a me vehementissime petierunt) viros eruditione non ignobiles, praeterea quoque inveniri homines, qui, nescio quid magni, circa divi Carthesii relictum Tractait de l'homme moliuntur in cassum; atque hanc ob causam harum expectationem explere, illorum vero conatus reddere irritos aequum mihi visum fuisse dum tibi una eademque opera satisfacerem."

26 For a thorough discussion of the difficulties of producing adequate images for the Traité de l'homme see Claus Zittel, Theatrum philosophicum: Descartes und die Rolle ästhetischer Formen in der Wissenschaft (Berlin, 2009), especially 306-348. 
return to this connection later; for now, it is important to recognize that De Bils was well informed about Descartes' work, whose title he mentioned in French, and about the interpretative difficulties, in the years immediately preceding the publication of this Cartesian work. Moreover, his claims might have carried meaning beyond the mere illustration of the text, as he embraced a mechanistic physiology that simultaneously strengthened, clarified and extended Descartes' theory.

It should, in fact, be noted that De Bils' conception of the lymphatic circulation went beyond the Cartesian text while maintaining its basic explanatory model. He made this point clear in a letter written in 1668 as an answer to some questions that his Cartesian friend, Andreae, had posed. De Bils' definition of the vessels as 'ferment-vessels' leading the lymph to the center had a Cartesian bent. In light of Descartes' criticism of Harvey, the investigation of the mechanisms of transportation in a fermenting material implied the strengthening of the Cartesian 'party.' However, De Bils enlarged the interpretative scheme by affirming that it is a stream of lymph from the center to the periphery that conveys the nutritious juice to the limbs. As explained in the abstract of his letter to Andreae, which was immediately translated into English and published in the Philosophical Transactions:

To your Quaere, Whether the said Ferment-vessels discharge at last all their Ferment into the Ductus Thoracicus, thence to be carry'd directly to the Heart, there to increase and to ferment the Blood, or whether they communicate their Ferment to other parts also? I answer, that most of the Juyce of the Milky vessels is discharged between the Tunicles of the Veins, Arteries, Lymphaticks, Membrans and the vessels in the Mesentery, to be conveyed into all the parts of the Body, both Internal and External. ${ }^{27}$

According to De Bils, the 'milky vessels' transported bodily humors and alimented liquids as different as the amniotic liquid, the gastric juice and saliva. While the Cartesian theory of blood fermentation could be seen as the hermeneutic framework of De Bils' study, discussion and explanation of the function of the lymphatic vessels, empirical observation induced him to develop a more general theory of the liquids' circulation within the framework of a post-Carte-

27 De Bils, "An Extract of a Letter, Lately Written by Monsieur Louys de Bills to D. Tobias Andreae Professor of Physick and Philosophy at Duysborgh on the Rhyn; Touching the True Use of the Lymphatick-Vessels," Philosophical Transactions of the Royal Society, 3 (1668), 791-796. 
sian mechanistic physiology, in which blood fermentation played a crucial explanatory role.

\section{Bilsian Controversies and Cartesian Physiology}

Satisfied with his observations and his broadly Cartesian interpretation, De Bils claimed as early as in 1660 that he could rapidly dispel misconceived treatments of the lymphatic system in ancient and recent books. He criticized and named several of the most eminent scholars of his time, including the Leiden anatomist van Horne, the French physiologist Jean Pecquet, the Danish anatomist Thomas Bartholin, the Swede Olaus Rudbeck, and the Leiden professor of medicine, Franciscus de le Boë Sylvius.

Soon they will realize [manu palpabunt] that today nobody knows the origin of the lymphatic vessels with enough clarity. My [theory of the] dew-carrying duct - contrary to the opinions of Pequet, van Horne, Bartholin, Rudbeck, de le Boe and anybody else - contains a different humor, destined to a different aim than the conversion into blood. They have never grasped the reason for which it is poured into the veins. This is shown by a comparison between their books and tables and a dog that I dissected. Hence, come, men such as we are, who are not of fictive dignity and are not hindered by negligence! Anybody can learn in less than one hour and without costs more than he can get elsewhere with great waste of time and money. Come freely [...]. From an autopsy you will get all [the knowledge] that I acquired better and clearer than from many words. ${ }^{28}$

De Bils' attack on the medical establishment ignited a medical controversy that divided the scientific community. Polemic writings appeared in rapid

28 De Bils, Omnibus verae anatomes studiosis, f. 2 v: "Breviter manu palpabunt nemini in hunc diem originem cursumque vasorum lymphaticorum satis liquere, ductumque meum roriferum contra quam sentiunt Viri magni Kapetius [sic!], Hoornius, Bartholinus, Rubecius, Silvius, vel quisque fuerit, alium plane humorem continere, alium in finem destinatum quam ut in sanguinem verti possit, quin etiam nunquam ab illis visum esse qua ratione in venas effundatur. Hoc libri eorum et tabulae cum cane a me dissecto collate testabantur. Accedant igitur, nec imaginaria dignitate hominum, quales nos sumus, ne incuria praepediti, qui volent, quibusque est integrum hora non integra plura addiscere citra expensas, quam cum annorum nummorumque dispendio alibi unquam assequantur. Accedant inquam libere; [...] omnia, quae in me recipio melius clariusque ex autopsia perceperint quam verbis expressis [...]." 
succession. In spite of their earlier alliance, Van Horne distanced himself from De Bils as early as in $1660 .{ }^{29}$ By contrast, Deusing, in his Exercitationes physicoanatomicae, de nutrimenti in corpore elaboratione [Physico-Anatomical Exercises on the Body's Assimilation of the Nutriment] (1660) and in a Dissertatio epistolica de hepatis officio [Epistolary Dissertation on the Function of the Liver] (166o), supported De Bils. Then again, the renowned Danish anatomist Thomas Bartholin rejected the validity of De Bils and Deusing's observations and theories in his Dissertatio anatomica de hepate defuncto [Anatomical Dissertation on the Liver's Death], which was published in $1661 .{ }^{30}$ Indeed, De Bils' idea that the lymphatic vessels are also directed toward the periphery was to be disproven in 1665 when, after many sections and animals' vivisections had been carried out, a promising young student of Van Horne's, Frederik Ruysch, detected valves in the lymphatic vessels which clearly would have impeded the centrifugal flow of the lymph. ${ }^{31}$

Prior to that year, however, the polemic raged unstopped. The Rotterdam anatomy professor, Nicolaas Zas, authored an Epistola apologetica [Apologetic Epistle] (1661) in support of De Bils, to which Bartholin reacted with a Responsio de experimentis anatomicis Bilsianis [Response to De Bils' Anatomic Experiments] (1661). ${ }^{32}$ Among other things, Bartholin questioned the ethical legitimacy of De Bils' embalmment of bodies, which contravened the corruption to which they are destined by Nature and God. ${ }^{33}$ He moreover criticized De Bils' secrecy as contrary to the common good to which science and medicine aspire. ${ }^{34}$ Van Horne's pupil, the anatomist Nicolaus Steno, sided with Bar-

29 Joann van Horne, Waerschouwinge aen alle lieffhebbers der anatomie, teegens de gepretendeerde weetenschap... van Jonchr. Louijs de Bils [A Warning to all Lovers of Anatomy, Against the Pretended Science of Louis de Bils, Esq.] (Leiden, 1660).

30 Cf. Trevisani, Descartes in Germania, 141.

$31 \quad$ Ruysch communicated his discovery in the Dilucidatio valvularum in vasis lymphaticis et lacteis (The Hague, 1665), which he dedicated to Sylvius, Van Horne and to the translator of Descartes' Traité de l'homme, Florentius Schuyl. See the insightful introduction to the facsimile edition by Antonie M. Luyendijk-Elshout, in Frederik Ruysch, Dilucidatio valvularum in vasis lymphaticis et lacteis (1665) (Nieuwkoop, 1964), 7-50.

32 Nicolaus Steno, Observationes anatomicae, quibus varia oris, oculorum, et narium vasa describuntur, novique salivae, lacrymarum et muci fontes deteguntur, et novum nobilissimi Bilsii De lymphae motu et usu commentum examinatur et rejicitur (Leiden, 1662); Nicolaas Zas, Epistola apologetica ad magnum Th. Bartholinum de calumniis nobiliss. Ludovico Bilsio... Arcanorum naturalium scrutatori subtiliss. (Rotterdam, 1661); Bartholin, Responsio de experimentis anatomicis Bilsianis (Copenhagen, 1661).

34 Ibid., 8. 
tholin. He issued a volume of anatomical observations entitled Observationes anatomicae (1662), which was directed against De Bils.

In this polemical context, the appearance of Descartes' posthumously published writings on physiology contributed an additional element to the ongoing debate. In 1662 the Leiden professor of philosophy Florentius Schuyl published René Descartes' De homine, laying the basis for his Blitzkarriere in the Faculty of Medicine, in which he was appointed as a professor in $1664 .{ }^{35} \mathrm{~A}$ rival French edition appeared two years later. In addition, Descartes' Traité de l'homme was printed in Paris in 1664, its text enriched with technical drawings by the Louvain professor Van Gutschoven and the physician Louis de la Forge, the latter the author of the occasionalist treatise on the relation between soul and body, Traitté de l'esprit de l'homme [Treatise on Human Spirit] (1666). De Bils had meanwhile been banned from the Leiden circle but still benefitted from support in Louvain.

It was Van Gutschoven who had issued the favorable report on De Bils' embalmed bodies in 1662, and who had prompted the University of Louvain to acquire his specimens. ${ }^{36} \mathrm{He}$ eventually attracted De Bils to Louvain in 1663 with the support of the Governor of the Southern Netherlands, John of Austria. The University bought five embalmed bodies together with the recipe of the secret embalmment method. Following the agreements, De Bils was expected to teach his techniques to Van Gutschoven. Moreover, he was given the responsibility of establishing an anatomy theater and was accorded an honorary professorship.

Given this context, it is likely that the anatomical engravings that Van Gutschoven produced for the 1664 edition of the Traité de l'homme were also based on De Bils' specimens. For instance, the drawing of a section of the brain (fig. 1) showing the pineal gland and the nerves connecting the brain with an eyeball is reminiscent of some of De Bils' specimens displaying these parts, as described by Van Gutschoven in 1662:

Moreover, the cranium is opened so that one can see the dura mater that envelops the brain, which is displayed and can be observed in all parts. The cerebellum follows with seven pairs of nerves and the admirable net. The eyes, beard, eyebrow and the hair are preserved as well as the nose so that those who saw that body alive can recognize it. The second body is

\footnotetext{
35 Cf. "Avertissement," in Descartes, CEuvres, 11:i-vii. On the Blitzkarriere, cf. Zittel, Theatrum philosophicum, 310, $788 \mathrm{n}$.

36 See Cleselier's preface to the 1664 edition of the Traité de l'homme, in Descartes, CEuvres, 11: xiii.
} 


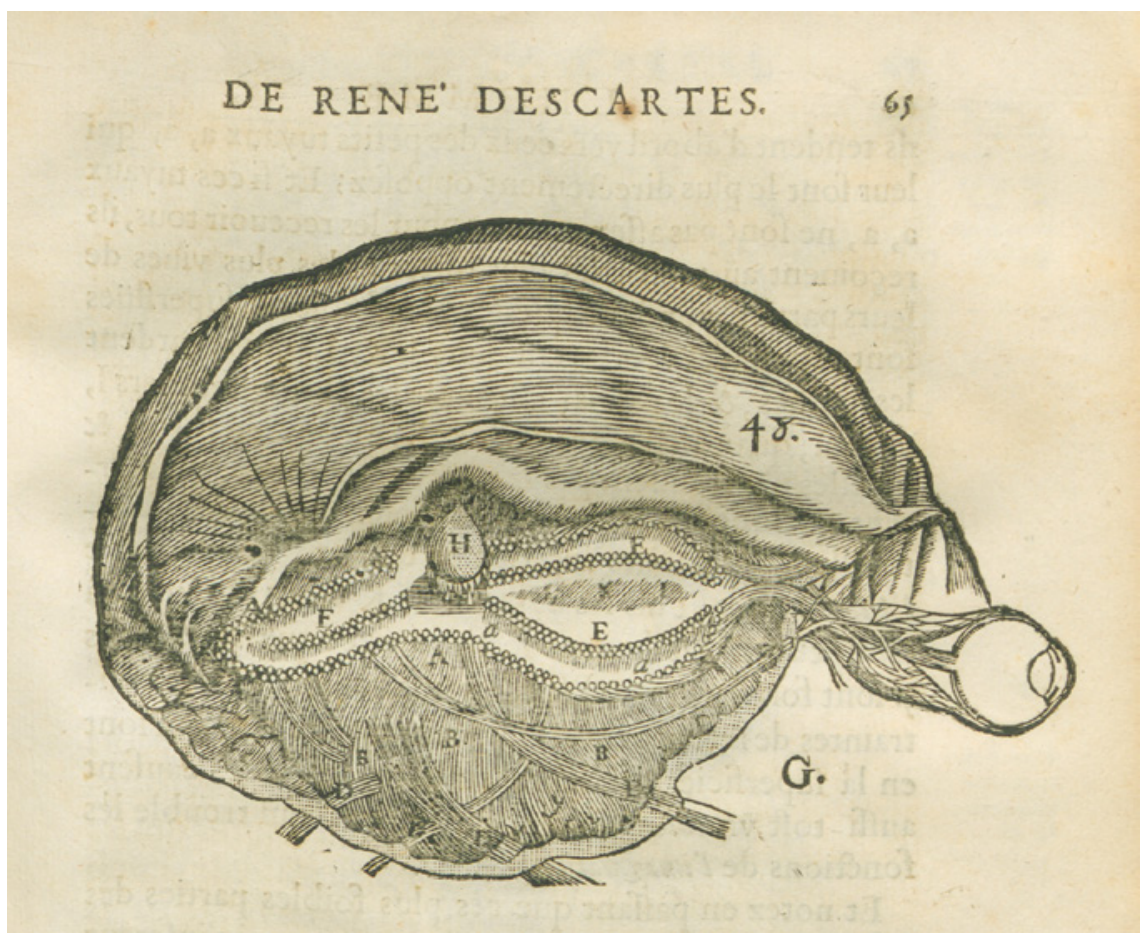

FIGURE 1 Van Gurschoven's famous illustration for Descartes' Homme (1664), p. 65, was possibly drawn using De Bils' embalmed cadavers. Provenance: Library of the Rostock University (Ec-1007).

that of a man, too. It is treated; the skin is not dissected; the breast and the hypochondric region are open. There, one can detect all noble organs, kept separated in an ingenious manner. The cranium is opened as well, around which one can find the pericranium, partially separated from the cranium. Inside, the dura mater and the pia mater, with the whole brain, occupy their natural place. ${ }^{37}$

37 Van Gutschoven, Repertum, 27: "Preaeterea elevato cranio, mater dura detegitur cerebrum involvens, qua sublata, undiquaque consideratur: inde sequitur cerebellum cum nervorum paribus septem atque reti admirabili. Oculi, barba, supercilia atque capilli etiam servata sunt, ut et nasus, omnia integra, ita ut qui hoc corpus olim vivum viderint, illud agnoscere possent. Secundum corpus est etiam viri, conditum, cute haud dissecta, pectore et hypochondriis apertis, ubi etiam omnes partes nobiles deteguntur, ingegnose separatae; aperitur etiam cranium, quod circum reperitur peri cranium, partim ab ipso cranium separatum, intus sunt dura et pia mater cum toto cerebro, naturali suo situ." 
The production of new images and books had been indeed part of De Bils' project from its inception. In 1662, he intended to treat "almost fifty Bodies differently dissected and embalmed; according to which, pictures may be drawn and engraven in Copper, and Books may be written."38

In the end, the Louvain experience was not a success. Doubts about the quality of De Bils' embalmed bodies originated from the fact that the five bodies that he had sold to the University of Louvain deteriorated. Moreover, he had been accused of failing properly to embalm an aristocrat, the Count of Hautreppe, who wished in his testament to have his body preserved. De Bils thus sought his fortune elsewhere, retired to his new fiefs in 's-Hertogenbosch and Sint Oedenrode, and was appointed honorary professor of anatomy at its local school. Beginning in 1669 he started a series of anatomical demonstrations with Tobias Andreae that were, however, brought to a halt by his death. ${ }^{39}$

De Bils' last will, in Dutch, included information about his secret techniques of embalmment and dissection without the loss of blood. The beneficiary was his wife, Elisabeth van Peene. It seems that Dr Bils' widow tried to sell these secrets to the government of Amsterdam, with the help of Tobias Andreae, but they were not successful, possibly owing to Ruysch's opposition. ${ }^{40}$

\section{Andreae's Association with De Bils}

De Bils' associate Andreae was from Bremen. In his early years he had studied under the guidance of several well-known German Cartesians. He was one of the students who followed Johannes Clauberg and Christoph Wittich in $165^{2}$ when they were forced to leave Herborn due to being accused of illegitimately teaching Cartesian novelties; they moved on to the Gymnasium of Duisburg, which was soon to be elevated to the status of a university. ${ }^{41}$ Andreae's subsequent iter studiorum was quite intricate: after an early education in Bremen (1650), Herborn (1651) and Duisburg (1652), he continued his studies in two centers of Dutch Cartesianism, Leiden (1654) and Groningen (1655). Back in Leiden, he received a medical education (1658), which he completed at

\footnotetext{
$38 \quad$ De Bils, Coppy, 6.

39 See Harold J. Cook, Matters of Exchange: Commerce, Medicine, and Science in the Dutch Golden Age (New Haven, Cт, 2007), 275-276.

40 For De Bils' testament see Jansma, Louis de Bils, "Bijlagen" I and II, 96-113. On the idle attempts to sell his secrets, cf. ibid., 11 and 90.

41 See Trevisani, Descartes in Germania, 27.
} 
Duisburg under Clauberg in $1659 .{ }^{42}$ During the following three years he lived in the Netherlands, in Rotterdam and Leiden. In 1659, he met De Bils and soon became his trusted assistant. ${ }^{43}$ In 1662 Andreae was appointed professor of medicine in Duisburg, and he occupied this chair until 1669. ${ }^{44}$

From Duisburg, Andreae wrote the abovementioned letter to De Bils asking for a clarification of his views on the lymphatic system (17 July 1668). That letter, which touched upon physiological issues of relevance to Cartesian theory (in particular on blood fermentation and the heartbeat), was originally written in Dutch. A partial English translation appeared in the Philosophical Transactions as early as in 1668; and eventually, Andreae published a Latin version (Marburg, 1678).

On 13 June 1669 Andreae was, thanks to De Bils, appointed honorary professor of philosophy and medicine at the Gymnasium of 's-Hertogenbosch. In his later publication, Bilanx exacta (1682), Andreae recounted their collaboration and a series of public dissections of embalmed bodies, which he and De Bils conducted in the new anatomy theater of 's-Hertogenbosch:

I cannot deny that De Bils, with a small incision, opened the abdomen of the cadaver that he presented in 1669 in the public amphitheater of 's-Hertogenbosch to so many attentive and illustrious witnesses, with my assistance. [He did so] in order to bring out the intracutaneous liquid [from a place] where it had become excessively swollen. Nonetheless, he never extracted any internal organs from that opening in order to put them back in their natural position after a separated treatment or embalmment. To be sure, all those spectators (there was a pretty high turnout of them) were able to observe and discern with their own eyes that all these parts were connected according to the natural disposition. ${ }^{45}$

42 Ibid., 93-94 and 114.

43 Andreae, Bilanx exacta Bilsianae et Clauderianae balsamationis (Amsterdam, 1682), 25-26.

44 Trevisani, Descartes in Germania, 130.

45 Andreae, Bilanx exacta, 26: "Nam licet non diffitear, Bilsium in isto cadavere quod Anno 1669 in publico amphitheatro Sylvae-Ducis erecto, coram tot oculatis et magni nominis testibus, me ipsi assistente, praesentavit, abdomen, levi aliqua sectione facta, aperuisse, ut aqua intercutem, qua plus quam intumuerat, educeret, attamen neutiquam per hanc aperturam internas partes extraxit, ut, seorsim praeparatis seu balsamatis, rursus in Naturalem illarum situ reponere. Quippe nullus fuit ex omnibus spectatoribus (erat autem illorum satis magnus confluxus) qui non suis oculis aut conspexerit, aut cernere potuerit omnes istas partes sibi invicem naturali suo more annexas esse." 
Since rumors had been raised about De Bils' effective capacity to realize incorruptible dry specimens he planned an additional series of public demonstrations in the warm season:

For this particular reason [the spreading rumors], as soon as he received this cadaver on 9 June 1669 , he immediately communicated to everybody through weekly reports [...] that he wanted to display it in the theater of Silva Ducalis ['s-Hertogenbosch] on 9 August of the same year - that is, in the Dog Days - with my assistance. He would then continue with its dissection for seven or eighth weeks. As [...] he always invited people from distant places to assist such an excellent and unprecedented spectacle, [...] he did not want to (and should not) abandon his praiseworthy endeavor, for any reason at all. ${ }^{46}$

Additionally, Andreae published De Bils' response to his critics concerning the corruption of his Louvain specimens and the unsuccessful embalmment of the Count of Hautreppe. De Bils' version of the events is entitled Brevis atque compendiosa historia eorum, quae spectant Artem ac Scientiam condiendi balsamo, singulari methodo ac nulli hactenus communi, humana cadavera [Short and synthetic history of the events concerning the art and science of embalming human cadavers with a singular and so far unknown method]. ${ }^{47}$ In this apology, De Bils reconstructed the events that led to the corruption of the five incorruptible bodies sold to the University of Louvain: it took a long time to find an appropriate place for them, since they were first brought to rooms in the university and then to the public library. The bodies were packed and unpacked more than once, transported forth and back, and were exhibited quite late and provisionally. During what was a particularly hot summer they were taken to rest under the roof of the library, and forgotten there during the winter. The place, as De Bils complained, had no proper windows and was very humid.

46 Ibid., 28-29: "Haec praecipue de causa Bilsius postquam 9Juni 1669 hoc cadaver acceperat, statim toti mundo per relationes septimanarias, ex ordinatione Praepotentium Ordinum Generalium foederati Belgii, notum fecit, se velle hoc 9 Augusti eiusdem anni, qui in diebus canicularibus incidit, me ipsi assistente, in theatri Sylvae-Ducis erecto, ostendere, et in dissectione illius ad 7 aut 8 septimanas continuare. Cumque hac ratione, ad tam excellens et nullis unquam seculis visum spectaculum, longe dissitas etiam gentes invitare, semper ipsi animus fuerit [...] neutiquam ab hoc laudabili proposito resilire voluit, nec debuit."

De Bils, Responsio, 31-36. 
Consequently, the cadavers rotted away just like everything else in that space - even books. ${ }^{48}$

As to the reason for the unsuccessful embalmment of the count, De Bils protested that this was not due to his neglect, but rather due to the indecision of the testamentary executors. They first requested that he embalm the count using his most excellent method, which would cost the considerable amount of 6,00o florins. Long negotiations regarding the price followed. At the same time, the executors discussed the correct interpretation of the will of the deceased count. The heirs eventually chose a 'vulgar' and cheap preparation (for three hundred florins), but the decision was taken when the body was already irreparably damaged.

\section{Bilsian Experiments in Frankfurt (Oder)}

Andreae was appointed to the professorship at Frankfurt (Oder) in 1674. There, he continued the embalmment experimentation alone. The publication of his epistolary exchange with De Bils appeared in Marburg in 1678, with an introduction from the local professor of medicine, Descartes' follower Johann Jakob Waldschmidt. ${ }^{49}$ Waldschmidt announced:

De Bils' method rises again with great benefit for our art; it is brought back to life, augmented through new experiments accomplished by an indefatigable and very experienced man, Mr. Tobias Andreae, Doctor of medicine and very renowned Professor of this [art] in the Electoral Academy on the Oder. ${ }^{50}$

The booklet comprised a report on Andreae's embalmment experiments, as well as a letter authored by his cousin, the historian and theologian Samuel Andreae, on ancient methods devised for the preservation of cadavers. Tobias Andreae had requested that his learned relative report on rabbinic references to ancient techniques of preservation.

48 Ibid., 33 .

49 See Julius Leopold Pagel, "Waldschmidt, Johann Jakob," Allgemeine Deutsche Biographie, 45 vols. (Munich and Leipzig, 1875-1912), 40:721.

$50 \quad$ De Bils, Responsio ad epistolam Tobiae Andreae, "Ad lectorem," f. [1]r: "Prodit nunc denuo magno cum Artis nostrae emolumento Methodus Bilsiana balsamandi corpora, quae novis experimentis aucta reviviscit sub laboris indefessis Viri Experientissimi, Domini Tobiae Andreae, Medicinae Doctoris ejusdemque in Electorali Academia ad Viadrum Professoris longe Celeberrimi." 
In the introduction, Waldschmidt stressed the importance of Andreae's experiments for the scientific community, in particular scholars of the Academia curiosorum. ${ }^{51}$ Moreover, in his section on ancient methods to preserve cadavers Samuel Andreae asserted that the new Bilsian experiments should be welcomed by scientific academies such as the Royal Society and the Academia curiosorum and expressed his hope that his cousin would find wealthy patrons. ${ }^{52}$

We may profitably read Andreae's publication against the background of the developing Cartesian debates that were taking place. A sort of international Cartesian network had established itself between Germany, the Netherlands and northern Europe. In the midst of a polemic concerning the legitimacy of teaching Descartes at universities the Cartesian professor of mathematics at Frankfurt (Oder), Johannes Placentinus, had named all of his philosophical consociates in 1665 . In the dedicatory letter prefacing his Des-Cartes triumphans [Triumphant Descartes], which was addressed to the Electoral Prince Friedrich Wilhelm of Brandenburg, Placentinus first referred to his own professor from Groningen, Tobias Andreae (the homonymous uncle of the protagonist of this article). Additionally, he mentioned a French diplomat in Sweden, Hector-Pierre Chanut; two Groningen theologians involved in the Dutch controversies over Descartes, Samuel des Marets and Abraham van der Heyden; the Dutch philosopher and physician Johannes de Raey, who defended the reconcilability of Descartes with Aristotle; the physicians Cornelis van Hoghelande and Gualterus Mirkinius, as well as two Duisburg professors, Johannes Clauberg and Christopher Wittich. Eventually, Placentinus mentioned his friend Daniel Lipstorp of Lübeck, who defended Cartesian philosophy as the natural basis of the Copernican system. Andreae, just like Placentinus, considered his own philosophical activity as connected with a wide European intellectual endeavor.

Placentinus himself was, in any event, not successful in establishing the Cartesian doctrine at Frankfurt's Philosophical Faculty. Quite to the contrary, the staunch opposition of his Aristotelian colleagues and some theologians actually led to his eventual ban from the Faculty. In 1666 he was even locked out as he was diagnosed with a grave mental illness, that would not allow him to resume his chair. ${ }^{53}$

\footnotetext{
$5^{1} \quad$ Ibid., f. [1]v.

$5^{2}$ Samuel Andreae, Epistola ad Tobiam Andreae de balsamationibus veterum seu modo et ritu condiendi cadavera apud veteres (Marburg, 22 March 1678), in De Bils, Responsio, 44-51, at 46.

53 I discuss Placentinus, his network and his Cartesian polemics at Frankfurt (Oder) in "Cen-
} 
In this context the appointment of Andreae to the Medical Faculty appears to have enabled the reintroduction of Cartesian views, albeit in a faculty different from the philosophical and in another framework, defined by medical and empirical concerns. ${ }^{54}$

Tobias Andreae claimed exclusive knowledge of De Bils' secrets: "I do not believe that anybody in the world can better assess this practice than I." ${ }^{n 5} \mathrm{An}$ dreae thought that he had actually improved on De Bils' techniques, as he had succeeded in embalming birds with their feathers intact, and fish retaining their scales. Both the Responsio of 1678 and the Bilanx of 1682 included a brief report of the embalmment experiments conducted at Frankfurt (Oder), entitled "Short Extract of the Experiments on Cadavers Embalmed by Myself Following De Bils' Method in order to Determine How Long they can be Preserved from Putrefaction and Remain Usable for Dissections." ${ }^{56}$ The experimentum primum involved a talpula, a mole. The second involved a small bird, called in local German Seidenschwänschen (today Seidenschwanz, corresponding to the bombycilla garrulus, known in English as the 'Bohemian waxwing'). The third embalmment experiment was done on two fish, a pike (lucius) and a perch (perca). The next three experiments concerned the reproductive apparatuses of animals as well as embryology: the fourth one was the embalmment of a dog's uterus, the fifth a hen's egg, and the sixth the uterus of a sheep containing a small embryo. Andreae reported on the events that led to the last experiment as follows:

On 27 November 1676 , after slaughtering some sheep, a pharmacist found in the uterus of one of them a fetus that was almost perfectly formed and extracted it intact. As he observed that the uterus of another [sheep] also

tral European Polemics over Descartes: Johannes Placentinus and His Academic Opponents at Frankfurt on Oder (1653-1656)," History of Universities, 29 (2016), 29-64.

Andreae's approach to Cartesianism parallels developments in other parts of Europe in the same years, which reveal, as has been written, "two large phenomena in seventeenthcentury Cartesianism, first the widespread criticism and condemnation of Cartesian physics and second the multiplication of more empirical Cartesianism. There is surely a relationship between these two movements." Cf. Roger Ariew, "Censorship, Condemnations, and the Spread of Cartesianism," in Dobre and Nyden, eds., Cartesian Empiricism, $25-46$, at 25 .

55 Andreae, Bilanx exacta, 23: "Neque enim puto aliquem in mundo esse, qui de hoc negotio maturum magis judicium ferre possit quam ego."

56 "Breve extractum actorum in cadaveribus Bilsiana methodo a se balsamatis ad capiendum experimentum, quam diu absque putrefactione subsistere et ad dissectione apta existere possint." De Bils, Responsio, 39-44 and Andreae, Bilanx exacta, 118-133. 
contained an embryo, he made an incision in the opening of the uterus and removed a rudimental fetus still swimming in its liquid. He showed them to me and, at my request, gave them to me. I started embalming both on the same day and continued [the treatment] up to 26 January 1677 , that is, for eight weeks and five days. ${ }^{57}$

The last experiment of the series concerned two newborn children who had died shortly after birth. Here Andreae also provided details about the circumstances: in December 1676 an impoverished mother had given birth to a set of twins, a boy and a girl, who died short after their baptism. The poor woman abandoned their bodies and went to another village to beg. The Reverend Clement Brecht, pastor of St. Nicholas Church in Frankfurt, had received the children alive in the "womb of the Mother Church" (in Ecclesiae matris gremium) and intended to bury them now in the "womb of mother earth" (terrae matris gremio mandari). However, since that winter was particularly harsh, their bodies remained very well preserved for several days. Ten days after their birth (and death) they were still intact, and Reverend Brecht handed them over to Andreae. The physician immediately dissected the girl, in the presence of the pastor and several scholars of medicine. Since the boy's body was better preserved, he decided to embalm it. After eight weeks of treatment, on 22 February 1676 , Andreae started a series of dissections of the small body in the attendance of the usual witnesses. After the anatomical inspection (anatome), he laid the boy in a wooden basket (in lignea cistula) and kept him in a shadowy place of the museum for eight days. He intended to observe how the body would rot. However, since it showed no signs of corruption, after the eighth day he decided to convert it into a mummy.

More contextual information about this period of activity can be derived from the Bilanx exacta. Andreae explains to his cousin and correspondent Samuel that a serious ophthalmia, or inflammation of the eyes, forced him to interrupt his program; originally he had intended to compose an extensive work on anatomy complete with illustrative tables. After he recovered, he resumed his teaching duties with a series of medical-philosophical lectures. In

57 Andreae, "Breve extractum actorum in cadaveribus Bilsiana methodo a se balsamatis," in De Bils, Responsio, 43: "Anno 1676, d. 27 Nov. pharmacopoeus mactans oves, in unius utero foetum jam satis perfectum invenit, quem integrum exemii; observansque in alterius utero etiam embryonem contineri, incisionem in uteri orificio fecit, atque ita extra uterum rudimentum foetus adhuc in suo colliquamento natantis, produxit. Haec cum mihi ostendisset atque petenti concessisset, utriusque balsamationem eadem die suscepi, illamque usque ad Anni 1677 d. 26 Januar, hoc est, per septimanas octo et quinque dies, protraxi." 
his classes he dealt with Hippocratic aphorisms following the 'philosophical method' and relying on 'philosophical principles.58 This endeavor is documented by three Cartesian disputations on the psychophysical dualism and psychosomatic medicine defended in 1679 by Clemens Josef Brecht, the pastor's son and Andreae's student of medicine: De conjugio mentis et corporis [The Mind-Body Conjunction], De cura mentis per corpus [The Cure of the Mind through the Body], and De cura corporis per mentem [The Cure of the Body through the Mind]. ${ }^{59}$

From the Bilanx we learn that that Andreae also started a series of privatissimae, that is, anatomical meetings in his house, open to no more than thirty participants. But the meetings met with general indifference; he later complained that Frankfurt was not the place he had hoped it would be. The number of actual participants turned out to be small.

After I concluded the embalmment of that small child, about whom I report in the Short Abstract, I decided to organize his dissection and continue it for some weeks, in the form of a gathering [collegium] and in the presence of some curious spectators (whom I did not expect to be more than twenty-five or thirty, as I would have not been able to receive more than that). Therefore, I invited them to this spectacle with an announcement [programma] written in my own hand and displayed on both sides of the Church's double door for one entire Sunday. But no crowd gathered at all; among the ten or twelve students of medicine who took notice, only one enrolled in time for the gathering and offered a minimal part of what I asked: a minerval (i.e., a golden coin, commonly called ducat). ${ }^{60}$

58 Andreae, Bilanx exacta, 8.

59 See my paper: Pietro Daniel Omodeo, "Medizinische und dämonologische Abhandlungen über den psychophysischen Dualismus im deutschen Cartesianismus des 17. Jahrhunderts," Paragrana: Internationale Zeitschrift für Historische Anthropologie, 25 (2016), 130153 .

$60 \quad$ Ibid., 7-10: "Postquam infantuli illius, de quo Breve illud Extractum meum loquitur, balsamationem absolvissem, constitueram illius dissectionem per aliquam septimanas continuas, sub forma Collegi, coram quibusdam curiosis Spectatoribus (quos ultra 25 et 30 non expetebam; quibus nec plures meum capere poterat) institutere. Hac de causa Programmate, manu mea conscripto et ad utriusque templi valvas per integram diem Dominicam affixo, illos ad hoc spectaculum invitabam; sed tantum abest ut confluxus aliquis fieret, quin inter 10 vel 12 studiosos Medicinae, qui tunc ibidem morabantur, unicus solum fuerit, qui in tempore ad hoc Collegium frequentandum nomen suum dederit, et exiguum illud, quod petebam, Minerval (scil: nummum aureum, ducatum vulgo dictum) obtulerit." 
The main 'witnesses' (testes) in these sessions were Reverend Brecht, his son Clemens Josef (eiusdem filius, Theol[ogiae] et Medici[nae] studiosus), who served as a chirurgus, and an ingenious sculptor (sculptor, perhaps woodcut illustrator) who had previously been to Italy and had assisted anatomical operations there.

After these privatissimae, on the day of Saint Margaret at the end of August, Andreae started a series of public demonstrations in the anatomy theater. ${ }^{61}$ These public demonstrations followed De Bils' example and consisted in the dissection of some cadavers previously prepared for use. The meetings lasted eight weeks and were accompanied by weekly reports (relationes hebdomadales) or news (novellae). ${ }^{62}$ Afterwards, Andreae decided to continue his activities privately at his own place, and "to rejoice about these [embalmment practices] alone in my heart" (ut de istis solus in sinu meo gauderem). ${ }^{63}$

Andreae's vocabulary and expressions of pleasure connected with anatomical experimentation might look awkward to a modern reader. Andreae speaks of the anatomist's gaudium, calls his dissections margaritae (pearls) that should not be wasted by giving them to ignorant people incapable of appreciation, and refers to those assisting the dissections as curiosi spectatores (curious spectators), hinting at an almost mundane dimension of his practices. The model he had in mind was the Dutch one, where anatomy museums were attractions, and the selling of biological specimens was a remunerable business. Brandenburg proved to be quite a different setting, far from the Dutch bourgeois market society and less receptive to novel scientific trends and their spectacular mise en scène.

\section{Andreae's Polemics against Clauder}

One year after Andreae had published his Frankfurt experiments in 1678, as an addition to De Bils' Responsio, Gabriel Clauder, court physician to the Dukes of Saxony and member of the Academia curiosorum, published his own work on embalmment techniques, the Methodus balsamandi corpora humana [Method for the Embalmment of Human Bodies] (1679), without taking Andrea's publication into consideration. As Andreae soon discovered to his great disappointment, this negligence led Clauder to form an uninformed opinion of De Bils'

\footnotetext{
$61 \quad$ Similar Collegia medico practica were established in those years in Leiden and Amsterdam; see Huisman, Finger of God, 94-97.

62 Andreae, Bilanx exacta, 10.

63 Ibid., 11.
} 
techniques. ${ }^{64}$ The preface starts with a celebration of the amazing advances of contemporary medicine and its allied disciplines:

"Africa always brings us something new!" So went the proverb in Ancient Rome. By receiving and varying it in our century we ought better to say: "Medicine, especially her daughters Anatomy and Chymistry [Chymia], always bring us something new." 65

Clauder listed De Bils' specimens among recent medical wonders. At the same time, he described them rather inaccurately, as can be seen, for example, in the following passage:

The Belgian Lodewijk de Bils exhibited his particular technique for the treatment of human cadavers to the erudite and curious world [Orbi erudito et curioso] with accurate elegance, although he also took recourse to evisceration. His disciples and imitators later devoted themselves to treating in the same manner insects and the internal organs of animals, separately. Others also preserve insects and small animals for a long time and intact, constantly immersed in special liquids and without evisceration. However, De Bils and the others kept all of these [techniques] so secret that others cannot guess anything, not even the details, of the matter and the means. ${ }^{66}$

Andreae reacted angrily to this uninformed description of De Bils' achievement, in particular to the insinuation that the secret of his techniques had been buried together with him.

Andreae responded in his Bilanx exacta Bilsianae et Caluderianae balsamationis, which was published in Amsterdam in 1682. In 1681, he had been

64 Gabriel Clauder, Methodus balsamandi corpora humana, aliaque majora sine evisceratione et sectione hucusque solita (Altenburg, 1679).

65 Ibid., f. )*(r: "Africa semper adportat aliquid novi! Romae antiquae hoc erat proverbium. Nos illud mutuantes et immutantes rectius Nostro hoc seculo dicimus: Medicina, et in specie ejusdem filia, Anatomia et Chymia, semper adportant aliquid novi."

66 Ibid.: "hinc Ludovicus de Bils, Belga, peculiare specimen in cadaveribus humanis adcurata elegantia sese commendans, concurrente tamen exenteratione, exhibuit Orbi erudito et curioso. Quod itidem postea in insectis ac visceribus Animalium seorsim tractatis praestiterunt aut eiusdem discipuli, aut aemuli. Alii etiam per tempus servant integra liquoribus quibusdam semper innatantia insecta et bruta minora non eviscerata. Quae tamen cuncta tam Bilsio, quam reliquis adeo occulte fuerunt peracte, ut nihil aut minimum saltem de materia ac modo adhibito subolfacere aliis licuerit." 
appointed professor of philosophy at Franeker, as the successor of Abraham Gulichius, a former Leiden pupil of Wittich, Johannes de Raey, Abraham van der Heyden and Johannes Cocceius. ${ }^{67}$ Did not the Saxony court physician consider empirical reports set in a Cartesian framework worthy of his consideration?

This 'balanced' assessment in fact severely criticized Clauder's negligence: how could he have ignored Andreae and De Bils' publications? Clauder claimed that De Bils' embalmment technique had irreparably got lost and such contention particularly offended Andreae, who regarded himself as the legitimate heir of his experimental practice. Also, the conviction that De Bils had produced his specimens by eviscerating the bodies was wrong. Had Clauder not seen the title of De Bils' Responsio ad epistolam Tobiae Andreae in the catalogue of the Frankfurt Book Fair? Moreover, had not Clauder's colleague Waldschmidt invited the members of the Academia curiosorum to review that publication? ${ }^{68}$ Clauder should at least have known of the extract from De Bils' considerations on the lymphatic system that had appeared in the Philosophical Transactions. ${ }^{69}$

Furthermore, Andreae regarded Clauder's statement that he had independently discovered De Bils' embalmment technique as an act of bragging and pretension. After all, Clauder was only able to produce mummies by drying up cadavers. In this respect De Bils' technique was superior. Andreae explained that Bilsian bodies could be dried and transformed into mummies in a second phase. He himself had been able to test this, as was reported in his previous publication. ${ }^{70}$ Perhaps Clauder had seen some of De Bils' mummies in Rotterdam, but he had clearly never inspected his most astounding specimens.

Andreae scorned Clauder's complaint about De Bils' secrecy. De Bils had been well aware of some scholars' indiscrete curiosity, and had therefore developed strategies to mislead them. For instance, he had let a foreign visitor believe that the embalmment method rested on transfusions:

Once, a doctor of medicine (if I am not wrong it was a German passing through Belgium and directed towards England and France) visited De Bils while he was passing through. He tried to penetrate his secrets asking oblique questions. De Bils made him believe that he had the intention of revealing something to him related to his embalmment technique and

\footnotetext{
67 Trevisani, Descartes in Germania, 153.

68 Andreae, Bilanx exacta, 12-13.

69 Cf. ibid., 114.

$70 \quad$ Ibid., 59 .
} 
anatomy. In all confidence and upon request to maintain absolute silence, he reported that he had discovered the art of blood transfusion and he used it to instill an embalming liquid into the cadavers, and so on and so on. After that, he dismissed him and bade him farewell, having made him hope that he had already reached the entrance hall of De Bils' secrets. In the end, thanks to that honest subterfuge, somebody else introduced to the world something useful and not contemptible. ${ }^{71}$

In this case, the positive outcome of setting a curious visitor on the wrong track was that the indiscrete guest took De Bils' method of transfusion abroad. Here, Andreae credited De Bils as the discoverer of transfusion, which, as he remarked, had by then become a heated topic in experimental medicine. ${ }^{72}$ As to the scholars' curiosity and De Bils' way of fooling them, Andreae reported his master's words:

This is the manner to give something into the hands of these overly curious scrutinizers, like a toy to children, with which they play and waste their time so that, at the same time, they stray from the way on which they hoped that they could reach this arcane knowledge. ${ }^{73}$

\section{A Cartesian Framework for Anatomical Experimentation}

Clauder despised philosophical speculations: he saw them as a corruption of medicine. In an empiricist vein he criticized his colleagues quarrelling over

Ibid., 81-82: "Evenit autem, ut quis Medicinae Doctor (ni fallor Germanus in Belgio promotus et inde in Angliam et Gallias tendens) Bilsium in transitu visitaret, atque etiam per obliquas quaestiones tentaret in arcana illius aliquo modo perrumpere. Bilsius autem simulans se ipsi aliquid revelaturum, quod balsamationem et anatomiam suam spectaret, sub fide et stipulatione omnimodi silenti, refert ipsi: se hanc artem transfundendi sanguinem invenisse et illa uti ad infundendum cadaveribus liquorem balsamantem etc. Quo facto illum spei plenum, quod jam saltem in arcanorum Bilsianorum vestibulo esset, constitutus demisit et Fatis commisit. Honesta tamen hac elusione, per alium quid in mundo, quod utilitatem suam habet, non contemnendam, introducens." (One of the referees suggested that the phrase "in Belgio promotus" might also mean that "the doctor of medicine" in question had "received his doctorate in Belgium." This might indeed be the case, but I incline to the other translation, above).

72 Cf. ibid., 81.

73 Ibid., 82: "Ita dandum est aliquid ejusmodi scrutatoribus nimis curiosis, tanquam pueris pupulam, in manus, quo ludant et tempus terant, simulque divertantur a via ista, qua arcana haec se perventuros esse sperabant." 
natural issues. As one can read in his Dissertatio de tinctura universali [Dissertation on the Universal Dye] (1678) he considered them to be too distant from anatomical practice and from the method of the greatest physician of the century, William Harvey:

If we enter the anatomy theater we enter Augean stables! In fact, among a thousand other Herculeses that are sweating and cleaning there, only Harvey now advances. How much time, sweat and hard work he invested in order to account for the generation of animals! How many months, even years, he had to spend before he could triumph by discovering the blood circulation. What shall I say about the confusion of theoretical controversies? What about the principles of the chemists, Galenists, Helmontians, Cartesians, Sylvanians, Charletonians, etc.? How much are human minds shaken, tormented, afflicted and troubled by that variety! In the end one can find neither the beginning nor the end of those controversies. $^{74}$

On the opposite side, De Bils and, even more so, Andreae saw their experimental practice as deeply connected with Cartesian anatomy and natural philosophy. We recall that De Bils had claimed that his embalmment techniques had been relevant to the realization of Descartes' Traité de l'homme. He most likely meant to imply that his specimens and dissection technique served as a basis for the posthumous edition of Descartes's work - and not that Descartes took advantage of them. Be that as it may, it seems that De Bils was acquainted with Descartes' Treatise on Man before it was published, and that the illustrator of the French edition, Van Gutschoven, was a supporter of De Bils' techniques. It

74 Clauder, Dissertatio de tinctura universali (vulgo lapis philosophorum dicta) (Altenburg, 1678), 2-3: "Theatrum Anatomicum si ingredimur, ingredimur sane Augiae stabulum! Inter mille enim alios Hercules ibi sudantes ac purificantes solus nunc prodeat Harveus: Quantum temporis, quantum sudoris, quantum laboris fastidiosi impendit ille, in dilucidando generationis animalium negotio? Quot perdidit menses, imo annos, antequam de inventa sanguinis circulatione triumphare valuerit. Quid dicam de farragine controversiarum theoreticarum? Quid de Principiis Chymicorum, Galenicorum, Helmontianorum, Cartesianorum, Sylvianorum, Charletonianorum, etc. Quomodo ingenia humana harum varietate agitantur, macerantur, cruciantur, turbantur? Ut proinde de hisce loquendi nec principium, nec finis fere sit inveniendus?" The Helmontiani are the followers of the Flemish Paracelsian physician Jan Baptist van Helmont; the Sylviani belong to the school of the Leiden professor of medicine, Franciscus de le Boë Sylvius; the Charletoniani are the followers of the English atomist philosopher Walter Charleton, author of Physiologia Epicuro-Gassendo-Charletoniana (London, 1654). 
is even possible that Van Gutschoven used his specimens as a model for his famous engravings. As Andreae was to write in his Bilanx, the embalmer revealed to the physicians aspects that had escaped all anatomists before him, and without these Decartes' Treatise on Man could not have been realized. ${ }^{75}$

Andreae made explicit the implicit connection between anatomical experimentation and Cartesian speculation on several occasions. At Frankfurt (Oder), as stated in the Bilanx, he devoted himself to Bilsian practices, which he perceived to be a reinforcement and extension of his philosophical principles.

At that time I was busy conducting experiments. In part, these made me more certain about the perfection of De Bils' embalmment technique. In part, their success showed me whether my own reasoning [cogitationes] concerning further [experiments] to be done could anticipate the results with the same certainty with which I had conceived them in my mind, on the basis of philosophical reasons [philosophicas rationes] I deemed to be solid. ${ }^{76}$

In another passage, Andreae refers to the convergent pleasures of philosophical meditation and anatomical practice by way of his Cartesian approach to Hippocrates:

After the pain was soothed, I took on public lectures again, in which I offered a comment of the Hippocratic aphorisms following the Method of Philosophy and relying on the Principles of Philosophy. In this manner, returning to the pleasure of the habitual Meditations, I could quench those cogitations that could be of greater relevance for the business of embalmment. So I pursued my work with great keenness and pleasure.

75 Andreae, Bilanx exacta, 9o. Cf. 100: "idque iuxta omnes illas utilitates, quae inde in Academias redundarent, et maxime in perficienda Anatomiae studia, quae illis excoluntur, et in specie ad Cartesii Tractatum de Homine elaborandum, sicuti Bilsius ipse in Epistolica Dissertatione ad amicum Roterdami impressa id affirmat." Andreae refers to De Bils, Epistolica dissertatio, 3 .

76 Ibid., 2: "Quippe eo tempore occupatus eram faciendis experimentis, quae me, partim de perfectionibus Bilsianae balsamationis, magis certum redderent; partim vero successu suo edocerent, an meae, quas de illa ulterius perficienda cogitationes formaveram, tam certae in eventu essent, ac eas mihi in mente mea, per philosophicas rationes, quas censebam esse solidas, proposueram." 
As a result, I could accomplish it in a shorter time than I myself had hoped. ${ }^{77}$

Andreae's word choice here reveals his Cartesian commitment: "methodus philosophicus," "principia philosophiae," "meditationes," "cogitationes." He even points to the foundational texts: Discourse on Method, Principles of Philosophy, and Meditations.

His philosophical commitment can also be evinced from the context. In fact, Andreae's teaching resulted in such disputations as the the aforementioned Cartesian theses defended by Brecht. They were a medical reworking of the Cartesian theme of psychophysical dualism, and offered an assessment of the body-mind relation in the light of its application to therapy. Andreae and Brecht, in fact, invited philosophically minded physicians to follow the examples of Hippocrates and Galen, who had founded their art on firm natural principles.

The trilogy of disputations was presented as a commentary on the Hippocratic aphorism (II 6) "Quicunque aliqua Corporis parte dolentes, plerumque dolores non sentiunt his Mens aegrotat" [Those who, suffering from a painful affection of the body, for the most part do not feel the pains, are ill in mind].$^{78}$ The connection of the soul with the body, as stated in De conjugio mentis et corporis [The mind-body conjunction], does not need to be demonstrated, since it is evident to the consciousness (coscientia). This can be shown by the perception of bodily pain or by the organist's perfect command of his fingers. ${ }^{79}$

As for the Cartesian problem of the mind-body interaction, Andreae and Brecht proposed an occasionalist solution to it. Since the connection between the two substances, res extensa and res cogitans, escapes our understanding, a philosophical deus ex machina was necessary to guarantee their psychophysi-

77 Ibid., 7-8: "Accessit postea, quod dolore hoc fere sedato redierim ad Lectiones publicas, in quibus, Methodo Philosophiae et ex Principiis Philosophiae, commentarium aphorismis Hippocraticis parabam. Hoc pacto enim ad Meditationum consuetarum delicias rediens, cogitationes, quae in balsamationis negotium intentiores esse poterant fere sunt extinctae. Ursi enim hoc opus cum magna aviditate et delectatione; unde etiam evenit ut illud breviore tempore, quam vel ipse sperassem, absolverim."

78 Cf. Hippocrates, Works, 4 vols. trans. W.H.S. Jones (Cambridge, MA, [1923] 1931), 4:110-111:

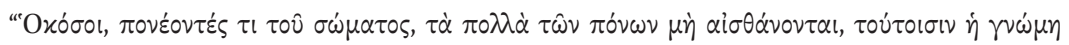

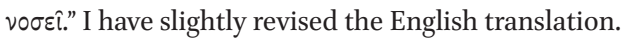

79 Andreae and Brecht, De conjugio mentis et corporis, f. A3r: "Prioris exemplum est dolor in Corporis [...]. Posterioris exemplum sit tremulus ille digitorum motus, quem organista suis digitis organo canens pro beneplacito suo indit; talis enim ex natura Corporis ejus naturaliter se habentis non flueret." 
cal interaction. ${ }^{80}$ Andreae and Brecht furthermore distinguished between three dimensions of human 'life:' the bodily life, the spiritual life, and the life of the compound. The bodily life is that of an automaton, that is to say, of an organism kept in motion by the circulation of blood and by fermentation. Intellectual life then corresponds to the perfect use of reason and will. The physician has to deal with the third form of life, namely that of the compound: "The life of the entire man is the strong and inner bondage between mind and body." 81 As far as the Hippocratic aphorism is concerned, the two Cartesian commentators explained this in terms of the sickness of the compound (morbus totius hominis), not of the soul alone. Due to the inner connection of the soul with the body they maintained that effective therapies should take into account both dimensions of the human being. Just as the decay of the organism affects the psyche, so do the passions of the soul bear consequences on organic functions and bodily health..$^{82}$

The Cartesian conception of human beings legitimized and fostered Andreae's experimental and medical practices. One might add that the idea that animals are automata without a soul may have legitimated cruel vivisections, a widespread contemporary practice for the investigation of blood circulation, the lymph, and functional physiology. ${ }^{83}$ In this respect the following theses defended in 1679 by Brecht, under Andreae's supervision, should be noted:

Thesis 19: [...] hence it is as incorrect to say that animals can feel [sentire] as it is to say that the snow feels the Sun $[. .$.

80 Cf. ibid., f. A3v: "Cum ergo Deum solus causa admirabilis hujus conjugii existat, non equidem inquiremus in modum, quo effecit ut duae hae substantiae realiter et essentialiter diversae in unum quid compositum quod Homo vocatur ita abierint, ut mentis voluntatem corpus recipiat, et motus corporis mens percipiat, quia hoc forsan sphaeram omnis finitae intelligentiae superat, nihilominus tamen, quia clare et distinctae [...] percipimus talem intimam conjunctionem mentis et corporis in nobis esse, ut illam negare, esset notram essentiam et existentiam abnegare, nulii dubitamus affirmare, hanc conjunctionem mentis et corporis nostri [...] in hoc consistere, quod mens et corpus in se mutuo agant, et se mutuo patiantur [...]."

81 Tobias Andreae and Clemens Joseph Brecht, De cura mentis per corpus (Frankfurt (Oder), 1679), f. Arr: "At denique totius hominis Vita est arctissima et intima illa Mentis et Corporis Conjunctio."

82 See Omodeo, "Medizinische und dämonologische Abhandlungen."

83 See, for instance, Bertoloni Meli, Mechanism, Experiment, Disease, 32-40. Between 1664 and 1668 about ninety vivisections were performed at the Royal Society. See Anita Guerrini, "The Ethics of Animal Experimentation in Seventeenth-Century England," Journal of the History of Ideas, 50 (1989), 391-407, at 395 . 
Thesis 20: Hence, it is incorrect to ascribe any senses to the animals and even pain. Nor may one properly say that an animal perceives or does not perceive the pain of its body. ${ }^{84}$

While such a Cartesian legitimation was not a conditio sine qua non, as vivisection was common among anatomists and experimenters both Cartesian and other, it is evident that Cartesian physiology offered an interpretative framework and contributed to making new anatomical practices acceptable and useful. ${ }^{85}$ Furthermore, it could free the experimenters from moral inhibitions. ${ }^{86}$

After he settled in Franeker, Andreae refrained from further medical practice and devoted himself to philosophy, directing mocking words at medical polemicists. After many years of medical teaching at Frankfurt he declared that he was now in a position to correct and consolidate his medical knowledge by founding it on firm philosophical grounds. Was philosophy not a universal medicament?

The fact that this profession [of philosophy professor] opens up for me a wider horizon of possible meditations also gives me the occasion to heal medicine itself, which has so far been miserably ill owing to so many defects, through philosophy (which is the true panacea), and to bring to it something more solid, following my own approach. Actually, my spirit

84 Andreae and Brecht, De conjugio mentis et corporis, f. Br-v: "Th. 19: [...] ex hoc tamen aeque minus proprie dici possunt bruta sentire quam nivem dicimus sentire Solem [...]. Th. 20: Improprie ergo sensus omnis atque ita etiam doloris bruto adscribuntur, nec proprie dici potest brutum dolorem corporis sui percipere aut non percipere."

85 See the discussion in Anita Guerrini, Experimenting with Humans and Animals: From Galen to Animal Rights (Baltimore, MD and London, 2003), ch. 2.

86 The Leiden anatomist Nicolaus Steno, one of those involved in the Bilsian polemics, was hesitant about experimenting on suffering dogs. As he wrote to Thomas Bartholin in 1661: "I must confess that it is not without abhorrence that I torture them [the dogs] with such prolonged pain. The Cartesians take great pride in the certainty of their philosophy, but I wish they could convince me as thoroughly as they are convinced that animals have no souls, and that it makes no difference whether you touch, dissect and devastate the nerves of a living animal or the cords of an automaton which is set in motion" (translation my own). See Bartholin, Epistolarum Medicinalium... Centuria III (Den Haag, 1740), 228: "licet fatear, me tam longis cruciatibus non sine horrore illos torquere. De Philosophiae certitudine multum gloriantur Cartesiani: vellem ita certo mihi persuaderent, ac ipsi sunt persuasi, nullam esse brutis animam: nec differre utrum bruti vivi nervos an automati, quod actu movetur, chordas tangas, disseces, uras [...]." Cf. Antonie M. Luyendijk-Elshout, "Introduction" to Ruysch, Dilucidatio valvularum in vasis, 36 . 
is more strongly attracted by this than by the manual operations of the anatomists. ${ }^{87}$

Andreae complained that he had not received the recognition at Frankfurt that he had expected and deserved, although he had directed all of his efforts towards the enhancement of the prestige of its Medical Faculty.88 At Franeker he felt that he could finally devote himself to philosophy, freed from the debasing quarrels of physicians. ${ }^{89}$ Actually, Cartesian principles could dispel all controversies because - this was Andreae's hope - the new philosophy would provide a better natural foundation on which physiology and medicine could be erected.

However, the primacy he accorded to philosophy in his late years should not obscure the continuing closeness of his Cartesian principles to his medical views, which had been so evident in his early activities and writings. In the context of the physiological, anatomical and philosophical debates of those years, Cartesian philosophy proved to be one of the elements contributing to the development of modern medicine. Its mechanical perspective was a point of reference in the Bilsian controversies, in the reception of De Bils, in his practices, and also in those of his follower Andreae. Andreae's Cartesianism offered a justification for new experimental practices as well as a framework within which these could be understood; at the same time, his philosophical views were implemented outside the realm of medical practice.

87 Andreae, Bilanx exacta, 11-12: "Nam hoc ipso, quod haec Professio mihi ampliorem ad varia meditanda apertura est campum, occasionem quoque dabit ipsi Medicinae, ex tot defectibus adhuc misere laboranti, per Philosophiam (ut veram panaceam) succurrere, illique aliquid soliditatis majoris, pro modulo meo, afferre. Ad quod etiam genius meus magis, quam ad operationes manuales Anatomicorum, propendet."

88 Ibid., 101.

89 Ibid., 109. 